\title{
PENGARUH MODEL PEMBELAJARAN ATTENTION, RELEVANCE, CONFIDENCE, AND SATISFACTION (ARCS) TERHADAP AKTIVITAS DAN HASIL BELAJAR IPS TERPADU DI SMP N 2 SAWAN
}

\author{
Made Santhi Hermaswari ${ }^{1}$, Made Ary Meitriana ${ }^{2}$, Lulup Endah Tripalupi ${ }^{3}$ \\ Jurusan Pendidikan Ekonomi \\ Universitas Pendidikan Ganesha \\ Singaraja, Indonesia
}

e-mail: santhi.herma2@gmail.com ${ }^{1}$, ary.meitriana@yahoo.co.id², lulup_tripalupi@yahoo.com ${ }^{3}$

\begin{abstract}
Abstrak
Penelitian ini bertujuan untuk mengetahui perbedaan aktivitas belajar dan hasil belajar IPS terpadu antara kelompok siswa yang dibelajarkan dengan model pembelajaran ARCS dengan model pembelajaran konvensional, perbedaan aktivitas belajar antara kelompok siswa yang dibelajarkan dengan model pembelajaran ARCS dengan model pembelajaran konvensional, dan perbedaan hasil belajar IPS terpadu antara kelompok siswa yang dibelajarkan dengan model pembelajaran ARCS dengan model pembelajaran konvensional pada siswa kelas VIII di SMP N 2 Sawan. Jenis penelitian ini adalah eksperimen semu dengan Non-Equivalent Post-Test Only Control Group Design. Populasi dalam penelitian ini sebanyak 160 orang siswa kelas VIII. Sampel penelitian ini siswa kelas VIIIB sebagai kelompok kontrol sebanyak 33 orang dan siswa kelas VIIID sebagai kelompok eksperimen sebanyak 32 orang yang dibentuk secara sengaja dengan menggunakan teknik purposive sampling. Selanjutnya analisis yang digunakan adalah uji Manova. Hasil penelitian menunjukkan bahwa terdapat perbedaan aktivitas belajar dan hasil belajar antara siswa yang dibelajarkan dengan model pembelajaran ARCS dengan model pembelajaran konvensional ditunjukkan dari nilai uji $F 71,905$ dengan nilai probabilitas $0,000<\alpha=0,05$, terdapat perbedaan aktivitas belajar antara siswa yang dibelajarkan dengan model pembelajaran ARCS dengan model pembelajaran konvensional ditunjukkan dari nilai uji $F$ 114,358 dengan nilai probabilitas $0,000<\alpha=0,05$, dan terdapat perbedaan hasil belajar antara siswa yang dibelajarkan dengan model pembelajaran ARCS dengan model pembelajaran konvensional ditunjukkan dari nilai uji $F 37,222$ dengan nilai probabilitas $0,000<\alpha=0,05$.
\end{abstract}

Kata kunci: model pembelajaran ARCS, aktivitas belajar, hasil belajar.

\begin{abstract}
This research aimed to find the differences of learning activity and learning outcomes of integrated IPS between group of students which is taught by ARCS learning model with conventional learning model, the differences of learning activity between group of students which is taught by ARCS learning model with conventional learning model, and the differences of learning outcomes of integrated IPS between group of students which is taught by ARCS learning model with conventional learning model at grade VIII students at SMP N 2 Sawan. This study was quasi experiment with Non-Equivalent Post-Test Only Control Group Design. Population as many 160 students of the VIII. Sample class VIIIB as control group of 33 students and student class VIIID as experiment group as 32 students with purposive sampling. The analysis used was Manova test. The result of research showed that there were differences of learning activities and learning outcomes between students who were taught by ARCS learning model with students who were taught by conventional learning model shown from value of $F$ test 71.905 with probability value $0.000<\alpha=0.05$, there was differences of learning activities between students who were taught by ARCS learning model with students who were taught by conventional learning model shown from value of $F$ test 114.358 with probability value $0.000<\alpha=0.05$, there was differences of learning outcomes between students who were taught by ARCS learning model with students who were taught
\end{abstract}


by conventional learning model shown from value of $F$ test 37,222 with probability value $0.000<\alpha=0.05$.

Keywords: ARCS learning model, learning activity, learning outcomes.

\section{PENDAHULUAN}

Dalam pembelajaran

perlu diperhatikan keterlibatan siswa dalam pengorganisasian pengetahuan apakah aktif atau pasif. Proses pembelajaran terdapat berbagai aktivitas yang terjadi baik fisik maupun non fisik. Menurut Sardirman (2007:100), aktivitas belajar adalah, "suatu kegiatan belajar mengajar yang terencana, terutama agar tercapai prestasi belajar yang diharapkan." Hamalik (2009:171) mengemukakan bahwa, "aktivitas belajar adalah suatu kegiatan yang dilakukan oleh siswa pada saat proses pembelajaran untuk mencapai hasil belajar." Hal serupa juga dikemukakan oleh Kunandar (2010:277) bahwa, "aktivitas belajar adalah keterlibatan siswa dalam bentuk sikap, pikiran, perhatian, dan aktivitas dalam kegiatan pembelajaran guna menunjang keberhasilan proses belajar dan memperoleh manfaat dari kegiatan tersebut."

Indikator yang digunakan untuk menilai aktivitas belajar siswa mengacu pada pendapat Keller (2010) yang didasarkan pada proses rancangan motivasi, yaitu: perhatian, relevansi, rasa yakin, dan rasa puas. Perhatian dapat ditunjukkan dengan siswa memperhatikan pelajaran saat berlangsung dengan baik dan antusias. Relevansi dapat ditunjukkan dengan siswa sering menjawab dan mengaitkan pembelajaran di kehidupan sehari-hari dengan jelas dan tepat. Rasa yakin dapat ditunjukkan dengan siswa sering bertanya dengan pertanyaan yang memerlukan analisa untuk menjawabnya. Rasa puas dapat ditunjukkan dengan kemampuan berbahasa dalam memberikan pendapat baik dan etika berbicara baik.

Hasil belajar merupakan salah satu indikator yang menunjukkan tingkat kemampuan dan pemahaman siswa dalam belajar. Serta hasil belajar adalah suatu kemampuan aktual yang dapat diukur secara langsung dengan tes. Menurut Sardiman (2007:51), hasil belajar adalah, "hasil langsung berupa tingkah laku siswa setelah melalui proses belajar mengajar yang sesuai dengan materi yang dipelajarinya." Menurut Sudjana (2010:15), hasil belajar adalah kemampuankemampuan yang dimiliki siswa setelah ia menerima pengalaman belajar. Sedangkan Asep (2010:14) mengungkapkan, hasil belajar adalah "kemampuan yang diperoleh siswa setelah melalui kegiatan belajar." Jadi dapat disimpulkan bahwa hasil belajar adalah perubahan tingkah laku dan kemampuan siswa yang diperolehsetelah menerima pengalama belajar serta kegiatan belajar mengajar berdasarkan pada materi yang dipelajarinya.

Menurut Nasution (2001:43), "Hasil belajar adalah penguasaan seseorang terhadap pengetahuan atau keterampilan tertentu dalam suatu mata pelajaran, yang lazimnya diperoleh dari nilai tes atau angka yang diberikan guru." Tes yang digunakan untuk menentukan hasil belajar diistilahkan dengan tes hasil belajar. Menurut Santrock (2008:606), "Tes hasil belajar dimaksudkan sebagai tes untuk mengukur apa yang telah dipelajari atau keahlian apa yang telah dikuasai siswa." Senada dengan itu, Sukardi (2007:139) menyatakan bahwa "Tes hasil belajar umumnya mengukur penguasaan dan kemampuan siswa setelah mereka selama waktu tertentu menerima proses belajar mengajar." Jadi, tes hasil belajar untuk mengukur tingkat penguasaan dan kemampuan siswa secara individual dalam cakupan dan ilmu pengetahuan yang telah ditentukan oleh para guru.

Model penilaian SMP pada penerapan KTSP oleh Badan Penelitian dan Pengembangan Departemen Pendidikan Nasional (2006) menunjukkan bahwa tes hasil belajar berupa tes pilihan ganda dapat digunakan untuk menilai kemampuan mengingat dan memahami dengan cakupan materi yang luas. Dengan demikian, indikator yang digunakan untuk mengukur hasil belajar siswa pada penelitian ini mencakup kemampuan mengingat dan memahami. Menurut Anderson \& Krathwol (2010), kemampuan mengingat dan 
memahami dapat dijelaskan sebagai berikut. Mengingat (remember), yaitu mengingat kembali pengetahuan yang relevan dari memori jangka panjang. Mengingat dapat ditunjukkan dengan kemampuan mendefinisikan atau menyebutkan suatu konsep. Memahami (understand): mengkonstruki makna dari pesan pembelajaran, termasuk komunikasi lisan, tertulis dan grafis. Memahami dapat ditunjukkan dengan kemampuan memberikan contoh, mengklasifikasikan, dan menjelaskan suatu konsep.

Dalam upaya meningkatkan mutu pendidikan harus diperhatikan komponenkomponen yang mempengaruhi proses pembelajaran. Komponen yang mempengaruhi proses pembelajaran ini berinteraksi antara satu dengan yang lainnya. Komponen tersebut adalah meliputi guru, peserta didik, materi pelajaran, media pembelajaran, strategi dan model pembelajaran serta sistem evaluasi hasil belajar yang menentukan berhasil atau tidaknya proses pendidikan (Slameto, 2010). Peranan guru dalam proses pembelajaran menjadi sangat penting, karena guru merupakan salah satu sumber belajar yang utama bagi siswa. Dalam melakukan kegiatan pembelajaran guru menggunakan model pembelajaran. Model pembelajaran dipilih dan disesuaikan dengan materi dan karakteristik siswa.

Ada banyak model pembelajaran yang dapat digunakan oleh guru dalam pembelajaran salah satunya adalah model pembelajan Attention, Relevance, Confidence, dan Satisfaction (ARCS). Model pembelajaran ini dikembangkan atas dasar teori-teori dan pengalaman nyata intsruktur sehinga mampu membangkitkan semangat belajar siswa secara optimal dengan aktivitas diri siswa sehingga didapatkan hasil belajar yang optimal. "Model pembelajaran Attention, Relevance, Confidence, dan Satisfaction (ARCS) merupakan suatu bentuk pemecahan masalah untuk merancang aspek aktivitas serta lingkungan belajar dalam mendorong dan mempertahankan aktivitas siswa untuk belajar" (Wena, 2009:33).

$$
\text { Model pembelajaran Attention, }
$$

Relevance, Confidence, dan Satisfaction (ARCS) ini berisi empat komponen, yaitu membangkitkan dan mempertahankan perhatian siswa dalam pembelajaran (Attention), materi pelajaran relevan dengan kehidupan siswa (Relevance), menanamkan rasa yakin dan percaya diri siswa (Confidence), menumbuhkan rasa puas pada siswa terhadap pembelajaran (Satisfaction). Kelebihan model pembelajaran Attention, Relevance, Confidence, dan Satisfaction (ARCS) adalah aktif memberi arahan yang harus dilakukan oleh siswa, penyajian materi dilakukan dengan cara menarik, bentuk pembelajaran berpusat pada siswa, meningkatkan motivasi untuk mengulang kembali materi agar menarik, meningkatkan karakteristik siswa agar pembelajaran lebih efektif. Sedangkan kelemahan model pembelajaran Attention, Relevance, Confidence, dan Satisfaction (ARCS) adalah hasil afektif siswa sulit dinilai secara kuantitatif, perkembangan secara kesinambungan melalui model pembelajaran ini sulit dijadikan penilaian.

Model model pembelajaran Attention, Relevance, Confidence, dan Satisfaction (ARCS) tepat untuk pembelajaran IPS terpadu hal ini berkaitan erat dengan karakteristik pendidikan IPS. Menurut Sapriya (2009:7), bahwa karakteristik pendidikan IPS adalah: bersifat dinamis, artinya selalu berubah sesuai dengan tingkat perkembangan masyarakat, IPS dihadapkan pada konsep dan kehidupan sosial yang mudah berubah sehingga siswa agar memiliki kebiasaan dan kemahiran untuk menelaah permasalahan kehidupan nyata pada masyarakat, mengutamakan peran aktif siswa melalui proses belajar inquiri agar siswa mampu mengembangkan berfikir kritis dan rasional, pembelajaran IPS tidak hanya mengutamakan pengetahuan semata juga nilai dan keterampilannya, pembelajaran IPS untuk memperhatikan minat siswa dan masalahmasalah kemasyarakatan yang dekat dengan kehidupannya.

Berdasarkan karakteristik tersebut, seharusnya pembelajaran IPS terpadu merupakan kegiatan pembelajaran yang menarik bagi siswa. Hasil wawancara dengan kepala sekolah dan guru mata pelajaran IPS di SMP $\mathrm{N} 2$ Sawan, pembelajaran IPS terpadu kelas VIII, 
aktivitas dan hasil belajar siswa masih rendah. Menurut guru rendahnya aktivitas belajar siswa disebabkan pada saat pembelajaran siswa terkadang tidak mendengarkan penjelasan dari guru, siswa kurang aktif dalam mengajukan pertanyaan dan mengemukakan pendapat, siswa tidak dapat menyelesaikan tugas yang diberikan oleh guru. Sedangkan pada saat penyampaian materi pembelajaran guru langsung menuju pada inti materi yang akan dibahas, tanpa menggali terlebih dahulu pengetahuan awal siswa tentang materi yang akan dipelajari dan pembelajaran konvensional yang didominasi oleh metode ceramah.

Akibat rendahnya aktivitas belajar siswa, hasil belajar siswa pun jadi rendah. Pada kelas VIII, masing-masing kelas memiliki hasil belajar yang berbeda. kelas VIII B nilai mata pelajaran IPS terpadu mengalami peningkatan nilai, sehingga nilai siswa tersebut rata-rata di atas Kriteria Ketuntasan Minimal (KKM), sedangkan dikelas VIII D nilai siswa cenderung belum mengalami peningkatan dalam mata pelajaran IPS terpadu, rendahnya hasil belajar siswa ini tampak dari hasil tes akhir semester. Nilai di bawah Kriteria Ketuntasan Minimal (KKM) yang ditetapkan sekolah yaitu 75, sehingga untuk mencapai Kriteria Ketuntasan Minimal (KKM) siswa perlu melakukan remedial.

Dalam proses pembelajaran diperlukan suatu model pembelajaran yang dapat meningkatkan aktivitas dan hasil belajar siswa. Namun, pada kenyataan dalam pembelajaran IPS terpadu di SMP N 2 Sawan belum membuat siswa menjadi aktif dalam mengikuti pembelajaran IPS terpadu. Berdasarkan hasil observasi awal dan hasil wawancara dengan kepala sekolah guru mata pelajaran IPS terpadu yang dilaksanakan di SMP $\mathrm{N} 2$ Sawan bahwa terdapat beberapa masalah dalam pembelajaran IPS terpadu yang menyebabkan aktivitas dan hasil belajar siswa rendah. Menurut guru rendahnya aktivitas belajar siswa disebabkan pada saat pembelajaran IPS terpadu siswa terkadang tidak mendengarkan penjelasan dari guru, siswa kurang aktif dalam mengajukan pertanyaan dan mengemukakan pendapat, siswa tidak dapat menyelesaikan tugas yang diberikan oleh guru. Sedangkan pada saat penyampaian materi pembelajaran guru langsung menuju pada inti materi yang akan dibahas, tanpa menggali terlebih dahulupengetahuan awal siswa tentang materi yang akan dipelajari dan pembelajaran konvensional yang didominasi oleh metode ceramah.

Dari permasalahan di atas, untuk meningkatkan aktivitas dan hasil belajar siswa, seorang guru dapat menggunakan model yang tepat dalam pelaksanaan pembelajaran. Salah satu model tersebut adalah model pembelajaran Attention, Relevance, Confidence, and Satisfaction (ARCS).Dengan model pembelajaran Attention, Relevance, Confidence, and Satisfaction (ARCS) diharapkan dapat meningkatkan aktivitas belajar dan hasil belajar siswa.

\section{METODE}

Jenis penelitian yang digunakan dalam penelitian ini adalah jenis penelitian quasi eksperimen. Penelitian quasi eksperimen bertujuan untuk memperoleh informasi untuk mengungkapkan hubungan sebab akibat dengan melibatkan kelompok kontrol dan kelompok eksperimen untuk mengontrol semua variabel relevan (Sugiyono, 2008). Rancangan penelitian yang digunakan adalah rancangan penelitian eksperimen dalam bentuk NonEquivalent Post-Test Only Control Group Design. Penelitian ini dilaksanakan di SMP $\mathrm{N} 2$ Sawan, yang beralamat di Jalan Singaraja-Sanih, Desa Bungkulan, Kecamatan Sawan, Kabupaten Buleleng, Provinsi Bali. Penelitian ini dilaksanakan secara kolaboratif dengan melibatkan guru mata pelajaran IPS terpadu pada kelas VIII SMP N 2 Sawan, dalam pelaksanaannya peneliti bertugas sebagai pengajar, sedangkan guru mata pelajaran IPS terpadu bertugas mengamati dan memberikan nilai pada lembar observasi aktivitas belajar dalam proses pembelajaran.

Prosedur penelitian dilakukan untuk menentukan tindakan-tindakan yang mengarahkan peneliti menjalankan penelitian. Langkah-langkah yang akan ditempuh dalam penelitian ini adalah 
orientasi dan observasi awal terhadap rancangan dan pelaksanaan pembelajaran untuk mengetahui keadaan kelas sebelum diberikan perlakuan, menentukan kelas yang digunakan untuk melakukan penelitian dengan melihat nilai akhir siswa, yang sudah dikonsultasikan dengan guru mata pelajaran IPS terpadu sehingga diperoleh kelas VIIIB sebagai kelas kontrol dan VIIID sebagai kelas eksperimen di SMP $\mathrm{N} 2$ Sawan, menentukan materi yang akan digunakan untuk penelitian yaitu materi peranan pasar bagi masyarakat, menyusun perangkat pembelajaran seperti: RPP dan LKS 1 Kompetensi Dasar untuk kelas eksperimen dan kelas kontrol yang dilaksanakan sebanyak 3 kali petemuan, 2 kali pertemuan memberikan treatment selanjutnya 1 kali memberikan post test yang dikonsultasikan dengan guru IPS terpadu dan dosen pembimbing, merevisi perangkat pembelajaran seperti RPP dan LKS untuk kelas eksperimen dan kontrol yang telah dikonsultasikan ke dosen pembimbing dan guru IPS terpadu, menyusun instrumen penelitian yang selanjutnya dikonsultasikan dengan dosen pembimbing dan guru IPS terpadu, memberikan perlakuan dengan menerapkan model pembelajaran Attention, Relevance, Confidence, Satisfaction (ARCS) di kelas eksperimen dan pembelajaran konvensional di kelas kontrol, merevisi instrumen penelitian yang telah dikonsultasikan dengan guru IPS terpadu dan dosen pembimbing, memberikan posttest yang sama yaitu tes materi peranan pasar bagi masyarakat kepada kelas kontrol dan kelas eksperimen, dan menganalisis data hasil penelitian untuk menguji hipotesis yang diajukan peneliti.

Dari 160 Orang siswa yang menjadi populasi, maka yang dijadikan sampel sebanyak 65 orang siswa. Dengan menggunakan teknik purposive sampling (pengambilan sampel yang digunakan secara sengaja). Sebanyak 33 orang siswa yang berasal dari kelas VIIIB dan Sebanyak 32 orang siswa yang berasal dari kelas VIIID. Dari 65 orang siswa sampel tersebut diberlakukan secara berbeda, untuk kelas VIIIB sebagai kontrol dan kelas VIIID sebagai kelas eksperimen.

Data yang diperoleh dari hasil penelitian ini adalah data kuantitatif. Data kuantitatif adalah data yang diperoleh dari hasil perhitungan angka-angka yang datanya didapatkan dari observasi aktivitas belajar dan tes hasil belajar yang diberikan kepada siswa mengenai penggunaan model pembelajaran Attention, Relevance, Confidence, Satisfaction (ARCS). Sumber data yang digunakan adalah data primer. Data primer diperoleh secara langsung dari sumber pertama, yaitu dari siswa kelas VIIIB dan VIIID di SMP N 2 Sawan. Data yang dikumpulkan dalam penelitian ini adalah data mengenai aktivitas belajar dan hasil belajar siswa terhadap penerapan model Attention, Relevance, Confidence, Satisfaction (ARCS). Adapun metode pengumpulan data yang digunakan dalam penelitian ini adalah sebagai berikut. Observasi, yang digunakan untuk memperoleh data mengenai aktivitas belajar dalam kegiatan pembelajaran. Alat pengumpulan datanya berupa lembar observasi mengenai aktivitas belajar siswa. Tes, yang digunakan untuk menilai hasil belajar yang diberikan pada siswa setelah diberikan pembelajaran 2 kali pertemuan dan akhir diberikan 1 kali post-test.

Data aktivitas belajar siswa dikumpulkan menggunakan lembar observasi aktivitas belajar siswa. Caranya dengan mengamati secara langsung kegiatan yang dilakukan siswa saat proses pembelajaran berlangsung. Penilaiannya dilakukan dengan melihat deskripsi dari lembar observasi aktivitas belajar siswa yang tertuang di dalam instrumen penelitian. Lembar observasi penilaian aktivitas belajar siswa terdiri dari 4 indikator aktivitas yang masing-masing memiliki lima deskriptor penilaian. Masing-masing aktivitas tersebut memiliki rentangan skor antara 1 sampai dengan 5 , sehingga skor aktivitas belajar maksimal yang bisa di dapatkan oleh siswa adalah sebesar 20 .

Data hasil belajar siswa diperoleh dengan instrumen berupa tes hasil belajar. Bentuk tes yang dikembangkan dan digunakan dalam penelitian ini adalah bentuk pilihan ganda. Sesuai dengan model penilaian SMP pada penerapan KTSP oleh Badan Penelitian dan Pengembangan Departemen Pendidikan Nasional (2006), tes hasil belajar berupa tes pilihan ganda 
p-ISSN : 2599-1418

e-ISSN : 2599-1426

digunakan untuk menilai kemampuan mengingat dan memahami. Kriteria penilaian tes hasil belajar siswa adalah setiap item jawaban benar diberikan skor 1 dan jawaban salah diberikan skor 0 .

Pengujian hipotesis yang digunakan dalam penelitian ini adalah uji MANOVA. Uji MANOVA (Multivariat Analisis of Variance) merupakan uji beda varian, jika pada ANOVA yang dibandingkan berasal dari satu variabel terikat, pada MANOVA yang dibandingkan berasal lebih dari satu variabel terikat. Untuk uji-t akan dilakukan uji normalitas dan homogenitas, sedangkan untuk uji MANOVA akan dilakukan uji normalitas, homogenitas varian, dan homogenitas matrik, setelah data dikatakan berdistribusi normal. Uji normalitas data digunakan mengetahui data berdistribusi normal. Data dikatakan berdistribusi normal apabila signifikansi yang diperoleh > 5\%. Uji normalitas dapat dilakukan dengan menggunakan bantuan program SPSS 24.0. for Windows. Uji homogenitas varian digunakan untuk memperoleh data empiris bahwa perbedaan yang terjadi pada uji hipotesis benar-benar terjadi akibat adanya perbedaan antara kelompok. Data dikatakan homogen apabila signifikansi
Jurnal Pendidikan Ekonomi Undiksha

Volume 10 No. 1 Tahun 2018

yang diperoleh > 5\%. Uji homogenitas varian dapat dilakukan dengan menggunakan bantuan program SPSS 24.0. for Windows. Candiasa (2011:38) menyatakan, "uji Homogenitas Matriks Varian/ Covarian dilihat dari hasil uji Box". Kriteria pengujian, jika angka signifikansi yang diperoleh lebih besar dari 0,05 maka hipotesis nol diterima. Artinya kelompokkelompok data yang dibandingkan memiliki varian yang homogen. Uji homogenitas matriks varian/covarian dapat dilakukan dengan memanfaatkan bantuan SPSS 24.0. for Windows.

\section{HASIL DAN PEMBAHASAN}

Berdasarkan hasil analisis data menunjukkan bahwa perbedaan aktivitas belajar dan hasil belajar antara siswa yang dibelajarkan dengan model pembelajaran Attention, Relevance, Confidence, Satisfaction (ARCS) dan model pembelajaran konvensional dapat diketahui dengan menggunakan uji manova. Rekapitulasi perhitungan uji manova menggunakan bantuan program SPSS 24.0 for Windows. Hasil uji manova dapat dilihat pada tabel

\section{Tabel 1. Hasil Uji Manova Untuk Pengaruh Model Pembelajaran Terhadap}

Aktivitas Belajar dan Hasil Belajar

Multivariate Tests

\begin{tabular}{|c|c|c|c|c|c|c|}
\hline & Effect & Value & $F$ & Hypothesis df & Error $d f$ & Sig. \\
\hline \multirow[t]{4}{*}{ Intercept } & Pillai's Trace & 0,998 & 18350,048 & 2,000 & 62,000 & 0,000 \\
\hline & Wilks' Lambda & 0,002 & 18350,048 & 2,000 & 62,000 & 0,000 \\
\hline & Hotelling's Trace & 591,937 & 18350,048 & 2,000 & 62,000 & 0,000 \\
\hline & Roy's Largest Root & 591,937 & 18350,048 & 2,000 & 62,000 & 0,000 \\
\hline \multirow[t]{4}{*}{ Kelompok } & Pillai's Trace & 0,699 & 71,905 & 2,000 & 62,000 & 0,000 \\
\hline & Wilks' Lambda & 0,301 & 71,905 & 2,000 & 62,000 & 0,000 \\
\hline & Hotelling's Trace & 2,320 & 71,905 & 2,000 & 62,000 & 0,000 \\
\hline & Roy's Largest Root & 2,320 & 71,905 & 2,000 & 62,000 & 0,000 \\
\hline
\end{tabular}

Berdasarkan hasil uji manova yang disajikan pada tabel 1 dapat diinterpretasikan bahwa nilai F-hitung untuk Pillai's Trace, Wilks' Lambda, Hotelling's Trace, dan Roy's Largest Root sebesar 71,905 dengan nilai signifikansi sebesar 0,000 . Nilai F-tabel pada df-pembilang $=2$ dan df-penyebut $=62$ adalah 3,15 . Nilai Fhitung $=71,905$ untuk Pillai's Trace, Wilks'
Lambda, Hotelling's Trace, dan Roy's Largest Root lebih besar dari F-tabel $=3,15$ dan nilai signifikansi 0,000 lebih kecil dari $\alpha$ $=0,05$. Jadi, dapat disimpulkan bahwa terdapat perbedaan aktivitas belajar dan hasil belajar antara siswa yang dibelajarkan dengan model pembelajaran Attention, Relevance, Confidence, Satisfaction (ARCS) dengan siswa yang dibelajarkan 
p-ISSN : 2599-1418

e-ISSN : 2599-1426

dengan model pembelajaran konvensional pada siswa kelas VIII SMP N 2 Sawan.

Berdasarkan hasil analisis data menunjukkan bahwa perbedaan aktivitas belajar antara siswa yang dibelajarkan dengan model pembelajaran Attention, Relevance, Confidence, Satisfaction (ARCS) dan model pembelajaran
Jurnal Pendidikan Ekonomi Undiksha

Volume 10 No. 1 Tahun 2018 konvensional dapat diketahui dengan menggunakan uji manova pada Tests of Between-Subjects Effects. Perhitungan uji manova pada Tests of Between-Subjects Effects menggunakan bantuan program SPSS 24.0 for Windows. Hasil uji manova pada Tests of Between-Subjects Effects dapat dilihat pada tabel 2 .

Tabel 2. Hasil Tests of Between-Subjects Effects Untuk Pengaruh Model Pembelajaran Terhadap Aktivitas Belajar

Tests of Between-Subjects Effects

\begin{tabular}{|c|c|c|c|c|c|c|}
\hline Source & $\begin{array}{c}\text { Dependent } \\
\text { Variable }\end{array}$ & $\begin{array}{l}\text { Type III Sum } \\
\text { of Squares }\end{array}$ & $d f$ & $\begin{array}{c}\text { Mean } \\
\text { Square }\end{array}$ & $F$ & Sig. \\
\hline Corrected Model & Aktivitas belajar & 52,331 & 1 & 52,331 & 114,358 & 0,000 \\
\hline Intercept & Aktivitas belajar & 13812,661 & 1 & 13812,661 & 30184,789 & 0,000 \\
\hline Kelompok & Aktivitas belajar & 52,331 & 1 & 52,331 & 114,358 & 0,000 \\
\hline Error & Aktivitas belajar & 28,829 & 63 & 0,458 & & \\
\hline Total & Aktivitas belajar & 13870,937 & 65 & & & \\
\hline Corrected Total & Aktivitas belajar & 81,160 & 64 & & & \\
\hline
\end{tabular}

Berdasarkan tabel 2 dapat diinterpretasikan bahwa nilai F-hitung sebesar 114,358 dengan nilai signifikansi sebesar 0,000. Nilai F-tabel pada dfpembilang $=1$ dan df-penyebut $=63$ adalah 4,00. Nilai F-hitung $=114,358$ lebih besar dari $\mathrm{F}$-tabel $=4,00$ dan nilai signifikansi 0,000 lebih kecil dari $\alpha=0,05$. Jadi, terdapat perbedaan aktivitas belajar antara siswa yang dibelajarkan dengan model pembelajaran Attention, Relevance, Confidence, Satisfaction (ARCS) dengan siswa yang dibelajarkan dengan model pembelajaran konvensional pada siswa kelas VIII SMP N 2 Sawan.
Berdasarkan hasil analisis data menunjukkan bahwa perbedaan hasil belajar antara siswa yang dibelajarkan dengan model pembelajaran Attention, Relevance, Confidence, Satisfaction (ARCS) dan model pembelajaran konvensional dapat diketahui dengan menggunakan uji manova pada Tests of Between-Subjects Effects. Perhitungan uji manova pada Tests of Between-Subjects Effects menggunakan bantuan program SPSS 24.0 for Windows. Hasil uji manova pada Tests of Between-Subjects Effects dapat dilihat pada tabel 3.

Tabel 3. Hasil Tests of Between-Subjects Effects Untuk Pengaruh Model Pembelajaran Terhadap Hasil Belajar

Tests of Between-Subjects Effects

\begin{tabular}{|c|c|c|c|c|c|c|}
\hline Source & $\begin{array}{c}\text { Dependent } \\
\text { Variable }\end{array}$ & $\begin{array}{l}\text { Type III Sum } \\
\text { of Squares }\end{array}$ & $d f$ & $\begin{array}{c}\text { Mean } \\
\text { Square }\end{array}$ & $F$ & Sig. \\
\hline Corrected Model & Hasil belajar & 1628,772 & 1 & 1628,772 & 37,222 & 0,000 \\
\hline Intercept & Hasil belajar & 369207,716 & 1 & 369207,716 & 8437,398 & 0,000 \\
\hline Kelompok & Hasil belajar & 1628,772 & 1 & 1628,772 & 37,222 & 0,000 \\
\hline Error & Hasil belajar & 2756,784 & 63 & 43,758 & & \\
\hline Total & Hasil belajar & 372926,346 & 65 & & & \\
\hline Corrected Total & Hasil belajar & 4385,556 & 64 & & & \\
\hline
\end{tabular}


Berdasarkan tabel 3 dapat diinterpretasikan bahwa nilai F-hitung sebesar 37,222 dengan nilai signifikansi sebesar 0,000. Nilai F-tabel pada dfpembilang $=1$ dan df-penyebut $=63$ adalah 4,00 . Nilai F-hitung $=37,222$ lebih besar dari $\mathrm{F}$-tabel $=4,00$ dan nilai signifikansi 0,000 lebih kecil dari $\alpha=0,05$. Jadi, terdapat perbedaan hasil belajar antara siswa yang dibelajarkan dengan model pembelajaran Attention, Relevance, Confidence, Satisfaction (ARCS) dengan siswa yang dibelajarkan dengan model pembelajaran konvensional pada siswa kelas VIII SMP N 2 Sawan.

Berdasarkan hasil penelitian yang diperoleh dapat dibuktikan bahwa terdapat perbedaan aktivitas belajar dan hasil belajar antara siswa yang dibelajarkan dengan model pembelajaran Attention, Relevance, Confidence, Satisfaction (ARCS) dengan siswa yang dibelajarkan dengan model pembelajaran konvensional, terdapat perbedaan aktivitas belajar antara siswa yang dibelajarkan dengan model pembelajaran Attention, Relevance, Confidence, Satisfaction (ARCS) dengan siswa yang dibelajarkan dengan model pembelajaran konvensional, dan terdapat perbedaan hasil belajar antara siswa yang dibelajarkan dengan model pembelajaran Attention, Relevance, Confidence, Satisfaction (ARCS) dengan siswa yang dibelajarkan dengan model pembelajaran konvensional pada siswa kelas VIII SMP N 2 Sawan.

Menurut Keller (2010), model pembelajaran ARCS merupakan suatu bentuk pendekatan pemecahan masalah untuk merancang aspek motivasi serta lingkungan belajar dalam mendorong dan mempertahankan motivasi siswa untuk belajar. Model pembelajaran ARCS dikembangkan berdasarkan teori nilai harapan (expectancy value theory) yang mengandung dua komponen, yaitu nilai (value) dari tujuan yang akan dicapai dan harapan (expectancy) agar berhasil mencapai tujuan itu. Keberhasilan belajar siswa dapat ditentukan oleh motivasi yang dimilikinya. Menurut Sanjaya (2009), siswa yang memiliki motivasi belajar yang tinggi cenderung prestasinya pun akan tinggi pula, sebaliknya siswa yang motivasinya rendah akan rendah pula prestasinya belajarnya. Tinggi rendahnya motivasi dapat menentukan tinggi rendahnya usaha atau semangat siswa dan tentu saja tinggi rendahnya semangat akan menentukan hasil belajar yang diperoleh. Berdasarkan teori tersebut dapat ditunjukkan bahwa model pembelajaran ARCS menekankan pada motivasi siswa untuk belajar sehingga aktivitas siswa semakin tinggi dalam proses pembelajaran. Hal ini didukung dengan hasil penelitian yang dilakukan oleh Aryawan (2014) bahwa terdapat perbedaan yang signifikan pada hasil belajar IPS antara kelompok model pembelajaran ARCS dan kelompok model pembelajaran konvensional.

Menurut Keller (2010), komponen model pembelajaran ARCS adalah Attention (A), Relevance (R), Confidence (C), dan Satisfaction (S). Menurut Wena (2014), dalam kegiatan pembelajaran attention atau perhatian tidak hanya harus dibangkitkan melainkan juga harus dijaga selama kegiatan pembelajaran berlangsung. Attention atau perhatian terhadap materi pelajaran akan muncul karena didorong oleh rasa ingin tahu. Selanjutnya, relevance dapat membuat siswa merasa kegiatan pembelajaran yang mereka ikuti memiliki nilai, bermanfaat dan berguna bagi kehidupan mereka. Menurut Uno (2010), siswa terdorong mempelajari sesuatu apabila yang dipelajari ada relevansinya dengan kehidupan mereka, dan memiliki tujuan yang jelas. Kemudian, confidence atau rasa percaya diri terhadap segala aspek kelebihan yang dimilikinya dapat membuat siswa merasa mampu untuk bisa mencapai berbagai tujuan di dalam hidupnya. Confidence atau rasa percaya diri dapat mendorong siswa agar berusaha dengan maksimal guna mencapai keberhasilan yang optimal. Menurut Bloom (2010), pemberian harapan kepada siswa dapat menggugah minat dan motivasi belajar asalkan siswa yakin bahwa harapannya dapat terpenuhi. Penghargaan dari orang lain seperti pengakuan, perhatian akan mampu menimbulkan rasa puas dan percaya diri akan kemampuan anak peserta didik. 
Tujuan dari model pembelajaran ARCS adalah untuk membuat siswa untuk lebih tertarik pada aktivitas belajar. Model pembelajaran yang dapat diterapkan untuk melibatkan siswa lebih aktif dalam proses pembelajaran salah satunya adalah model pembelajaran ARCS. Berdasarkan teori tersebut, penggunaan model pembelajaran ARCS dapat mengembangkan aktivitas belajar siswa, menggunakan sumber bahan ajar yang luas dan beragam, mengembangkan seluruh potensi siswa, mengembangkan keterampilan intelektual, dan berorientasi pada tindakan. Adanya motivasi yang kuat dalam diri siswa maka harapannya siswa dapat berpartisipasi aktif dalam pembelajaran. Hal ini didukung dengan hasil penelitian yang dilakukan oleh Kunardjiono (2012) bahwa penerapan model pembelajaran ARCS dapat meningkatkan aktivitas siswa pada mata pelajaran IPS. Hasil yang sama juga ditunjukkan oleh Pratiwi (2015) bahwa penerapan model pembelajaran ARCS dapat meningkatkan aktivitas siswa.

\section{SIMPULAN DAN SARAN}

Berdasarkan hasil analisis data dan pembahasan hasil penelitian maka dapat ditarik simpulan sebagai berikut. Terdapat perbedaan aktivitas belajar dan hasil belajar IPS terpadu antara kelompok siswa yang dibelajarkan dengan model pembelajaran Attention, Relevance, Confidence, dan Satisfaction (ARCS) dengan kelompok siswa yang dibelajarkan dengan model pembelajaran konvensional pada siswa kelas VIII di SMP N 2 Sawan tahun ajaran 2017/2018. Terdapat perbedaan aktivitas belajar antara kelompok siswa yang dibelajarkan dengan model pembelajaran Attention, Relevance, Confidence, dan Satisfaction (ARCS) dengan kelompok siswa yang dibelajarkan dengan model pembelajaran konvensional pada siswa kelas VIII di SMP N 2 Sawan tahun ajaran 2017/2018. Terdapat perbedaan hasil belajar IPS terpadu antara kelompok siswa yang dibelajarkan dengan model pembelajaran Attention, Relevance, Confidence, dan Satisfaction (ARCS) dengan kelompok siswa yang dibelajarkan dengan model pembelajaran konvensional pada siswa kelas VIII di SMP N 2 Sawan tahun ajaran 2017/2018.

Berdasarkan simpulan tersebut, beberapa saran yang diajukan dalam penelitian ini adalah sebagai berikut. Bagi guru disarankan untuk menyiapkan strategi agar pelaksanaan model pembelajaran Attention, Relevance, Confidence, dan Satisfaction (ARCS) dapat optimal dalam pembelajaran dengan cara: memaksimalkan tahap Attention dengan cara aktif merespon siswa, yaitu merangsang minat siswa dengan menggunakan interaksi pertanyaan responumpan balik, yang mempersyaratkan berfikir aktif, memaksimalkan tahap Relevance dengan cara menumbuhkan keakraban pada diri siswa terhadap pembelajaran dapat dilakukan dengan cara menggunakan atau pemakaian bahasa yang konkrit, contoh dan konsep yang berkaitan atau berhubungan dengan pengalaman dan fenomena kehidupan sehari-hari siswa, memaksimalkan tahap Confidence dengan cara membuat isi pembelajaran dari yang bersifat mudah ke sukar dan membuat pembelajaran yang sesuai dengan pengetahuan dan keterampilan siswa, guna menjaga tingkat tantangan atau kebosanan yang berlebihan, dan memaksimalkan tahap Satisfaction dengan cara menggunakan umpan balik motivasi yang positif dan menghindari pemberian penguatan yang dapat mengurangi motivasi, misalnya memberikan pujian yang berlebihan pada sesuatu yang sederhana. Bagi siswa disarankan untuk lebih aktif mencari sumber belajar lain sebagai tambahan referensi dalam pembelajaran tanpa menunggu perintah dari guru, karena pelajaran IPS adalah pelajaran yang sangat penting untuk semua bidang pekerjaan dan kehidupan sehingga perlu dipelajari.

\section{DAFTAR PUSTAKA}

Anderson, Lorin W. \& David R. Krathwohl. 2010. Kerangka Landasan Untuk Pembelajaran, Pengajaran, dan Asesmen, Alih Bahasa: Agung Prihantono. Yogyakarta: Pustaka Pelajar.

Aryawan, I K B M. 2014. Pengaruh Penerapan Model Pembelajaran Attention, Relevance, Confidence, Satisfaction 
p-ISSN : 2599-1418

e-ISSN : 2599-1426

(ARCS) dan Motivasi Berprestasi Terhadap Hasil Belajar IPS Pada Siswa Kelas V Sekolah Dasar Negeri di Gugus XIII Kecamatan Buleleng. Jurnal Penelitian Pascasarjana Undiksha, Vol. 4, No. 1.

Asep, Jihad. 2010. Evaluasi Pembelajaran. Yogyakarta: Mullti Pressindo.

Bloom, Benyamin S. 2010. Kerangka Landasan Untuk Pembelajaran, Pengajaran, dan Asesmen. Yogyakarta: Pustaka Pelajar.

Candiasa, I Made. 2011. Statistik Multivariant Disertai Aplikasi dengan SPSS. Singaraja: Unit Penerbitan IKIP Negeri Singaraja.

Hamalik, Oemar. 2009. Proses Belajar Mengajar. Bandung: Bumi Aksara.

Keller, J. M. 2010. Motivational Design for Learning and Performance: The ARCS Model Approach. New York: Springer.

Kunandar. 2010. Guru Profesional. Jakarta: Rajawali Press.

Kunardjiono. 2012. Penerapan Model Pembelajaran ARCS untuk Meningkatkan Aktivitas dan Hasil Belajar Mata Pelajaran IPS Siswa Kelas IV SD N Kotalama I Kecamatan Kedungkandang Kota Malang. Skripsi. Jurusan KSDP, FIP Universitas Negeri Malang.

Nasution, M. N. 2001. Manajemen Mutu Terpadu. Jakarta: Ghalia Indonesia.

Pratiwi, Rahmi. 2015. Penerapan Kolaborasi Model Pembelajaran ARCS (Attention, Relevance, Confidence, Statisfaction) dan Kumon Untuk Meningkatkan Aktivitas dan Hasil Belajar Akuntansi Siswa Kelas X Akuntansi SMK Negeri 1 Stabat Tahun Pembelajaran 2013/2014. Skripsi. Jurusan Pendidikan Akuntansi, Fakultas Ekonomi, Universitas Negeri Medan.

Sanjaya, Wina. 2009. Strategi Pembelajaran Berorientasi Standar Proses Pendidikan. Jakarta: Kencana.

Santrock, John W. 2008. Psikologi Pendidikan. Jakarta: Prenada Media Group.

Sapriya. 2009. Pendidikan IPS: Konsep dan Pembelajaran. Bandung: Remaja Rosdakarya.

Sardiman, A. M. 2007. Interaksi dan Motivasi Belajar Mengajar. Bandung: Rajawali Pers.

Slameto. 2010. Belajar dan Faktor-faktor Yang Mempengaruhinya. Jakarta: Rineka Cipta.
Jurnal Pendidikan Ekonomi Undiksha

Volume 10 No. 1 Tahun 2018

Sudjana, Nana. 2010. Dasar-dasar Proses Belajar Mengajar. Bandung: Sinar Baru.

Sugiyono. 2008. Metode Penelitian Kunatitatif Kualitatif dan $R \& D$. Bandung: Alfabeta.

Sukardi. 2007. Metodologi Penelitian Pendidikan. Yogyakarta: Bumi Aksara.

Uno, Hamzah B. 2010. Perencanaan Pembelajaran. Jakarta: Bumi Aksara.

Wena, Made. 2009. Strategi Pembelajaran Inovatif dan Kontemporer: Suatu. Tinjauan Konseptual Operasional. Jakarta: Bumi Aksara. 